\title{
PECULIARITIES OF ADMINISTRATIVE AND LEGAL REGULATION OF BUSINESS ENTITIES ACTIVITIES DURING THE QUARANTINE IN UKRAINE
}

The aim of the article is to investigate the peculiarities of administrative and legal regulation of the activities of business entities during quarantine and to consider possible directions of improvement of such regulation.

Methods. The theoretical and methodological basis of the research is modern general scientific and special legal methods and techniques of scientific knowledge. The formal and logical method determines the importance of administrative and legal regulation of the activities of economic entities during quarantine. Formal and legal method allowed analyzing the current legislative and other normative-legal acts concerning administrative and legal regulation of activity of economic entities during quarantine. The structural and logical, comparative and legal methods outline the main directions of improving of implementation the administrative and legal regulation of the activities of economic entities during quarantine.

Results. Attention is drawn to the fact that business entities are limited in their actions due to the introduction of quarantine and emergency regime in Ukraine. The article analyzes the legislative and other legal acts adopted to prevent the spread in Ukraine of acute respiratory disease COVID-19 caused by the coronavirus SARS-CoV-2, which regulate the activities of business entities. It is noted that the Government of the State, taking into account the important role of economic entities in the economy of the country, makes prudent measures to support them during quarantine. However, there are certain conditions under which business entities face problems that need to be addressed, primarily at the legislative level.

Conclusions. The article indicates the expediency of amending the current legislation to harmonize it in connection with the adoption of a number of regulatory acts aimed at preventing the spread of acute COVID-19 respiratory disease caused by the SARS-CoV-2 coronavirus in Ukraine and use in the legislation of different terminology related to COVID-19.

Key words: administrative-legal norms, coronavirus pandemic, emergency, counteraction to the coronavirus pandemic, benefits, responsibility of business entities. 


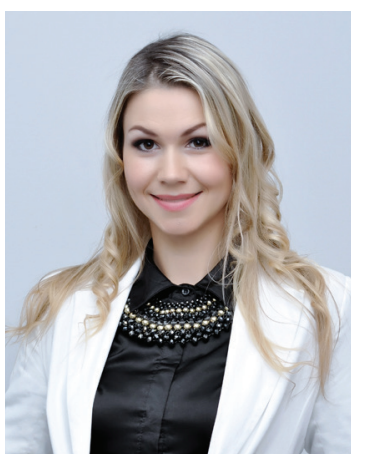

Liliia Popova, Professor of Finance and Credit Department Kharkiv National University of Civil Engineering and Architecture, Doctor of Law, Ph.D in Economy, Associate Professor orcid.org/0000-0001-8255-8363 Liliy.herman01@gmail.com

\section{Introduction}

Currently, there is a problem of the spread of acute COVID-19 respiratory disease caused by the SARSCoV-2 coronavirus in almost all countries of the world. Ukraine is no exception. One of the important steps aimed at overcoming the coronavirus pandemic is the introduction of effective measures by the authorities of each state. The introduction of total quarantine is precisely such a measure that can prevent as many people as possible from the disease not only within one country, but in almost all countries of the world. The Government of Ukraine has introduced restrictive measures that significantly affect the livelihoods of the population, as measures have been introduced to socially distance and mobilize the community to prevent infection and save lives. In these circumstances, the activities of business entities have also undergone significant changes.

The following scientists have devoted their attention to the issues of administrative and legal regulation of business entities activity and legal support for the control of the activity of business structures in Ukraine: O.M. Bandurka, O.O. Bandurka, O.I. Baranovsky, D.M. Bahrach, Yu.P. Bytyak, L.K. Voronova, M.I. Geets, O.P. Dysyak, M.M. Ermoshenko, M.I. Kamlyk, T.E. Koganovskaya, A.T. Komziuk, M.V. Kurkin, M.N. Kurko, M.P. Kucheryavenko, O.V. Pokataeva, S.M. Popova, V.P. Petkov, L.A. Savchenko, O.Yu. Sinyavska, O.P. Ugrowiecki, N.P. Flissak and others (Popova, 2018; Popova, 2019). In today's context, the question arises of the need to study the peculiarities of administrative and legal regulation of the activities of economic entities during quarantine due to the pandemic of coronavirus disease, which significantly changed the living conditions not only in Ukraine but in almost all countries of the world.

The aim of the article is to investigate the peculiarities of administrative and legal regulation of the activities of business entities during quarantine and to consider possible directions of improvement of such regulation.

2. The essence of state management of business activities during the quarantine

In order to prevent the spread of acute COVID-19 respiratory disease caused by the SARS-CoV-2 
coronavirus in Ukraine, a quarantine has been established throughout Ukraine on April 3, 2020 (Law of Ukraine № 1645-III, 2000; Resolution of the Cabinet of Ministers of Ukraine № 211,2020). The Government of Ukraine subsequently extended the quarantine decision in Ukraine until April 24, 2020 (The only web portal of the executive authorities of Ukraine "Government Portal"a) and then until May 11, 2020 (The only web portal of the executive authorities of Ukraine "Government Portal"b). An emergency regime has also been introduced throughout Ukraine (The only web portal of the executive authorities of Ukraine "Government Portal"c).

President of Ukraine Volodymyr Zelensky has signed, and the Verkhovna Rada of Ukraine passed, at an extraordinary meeting on March 17, 2020 laws aimed at combating the spread of coronavirus, in particular, on taxpayer support and on the availability of medicines and medical devices.

Legislative and other regulatory acts have been in place in Ukraine for the prevention of the spread of coronavirus disease in the territory of Ukraine in the treatment of "coronavirus COVID-19" or "coronavirus disease (COVID-19)" (Laws of Ukraine "On Amendments to some legislative acts of Ukraine aimed at preventing the emergence and spread of coronavirus disease (COVID-19)" (Law ofUkraine №530-IX, 2020), “OnAmendments to the Tax Code of Ukraine and Other Laws of Ukraine on Support of Taxpayers for the Period of Measures to prevent the emergence and spread of coronavirus disease (COVID-19)" (Law of Ukraine № 533-IX, 2020), the Decree of the Cabinet of Ministers of Ukraine "On the Prevention of COVID-19 Coronavirus Dissemination in the Territory of Ukraine" (Resolution of the Cabinet of Ministers of Ukraine № 211, 2020), "On Approval of the List of Medicines, Medical Devices and / or medical equipment necessary for the implementation of measures aimed at preventing the occurrence and spread, localization and elimination of outbreaks, epidemics and pandemics of coronavirus disease (COVID-19), which are exempt from import duties and operations for the importation into customs territory countries are exempt from tax on value added" (Resolution of the Cabinet of Ministers of Ukraine № 224, 2020) and so on.

By Resolution of the Cabinet of Ministers of Ukraine of April 2, 2020, № 255, certain amendments to the legislation concerning the prevention of the spread of the pandemic coronavirus in the territory of Ukraine were introduced. First of all, it should be noted that in the title and text of the Cabinet of Ministers of Ukraine of March 11, 2020, № 211, the interpretation "On Prevention of Spread of COVID19 Coronavirus in Ukraine" was replaced by the following: "On Prevention of Acute Respiratory Disease in Ukraine COVID-19 caused by the coronavirus SARS-CoV-2" (Resolution of the Cabinet of Ministers of Ukraine № 225, 2020). Corresponding changes have been made to the Cabinet of Ministers of Ukraine of March 16, 2020 № 215, March 20, 2020 № 242, March 25, 2020 № 239, and March 29, 2020 № 241. 
Therefore, in order to prevent inaccuracies in the legislative and other legal acts and to avoid confusion, it is advisable to make all relevant changes to the Ukrainian legislation.

Resolution of the Cabinet of Ministers of Ukraine of April 2, 2020 № 255 provides for strengthening of a number of quarantine measures, namely: prohibition of work of economic entities, which provides for the reception of visitors, in particular catering establishments (restaurants, cafes, etc.), shopping and entertainment centers, other entertainment establishments, fitness centers, cultural establishments, retail and consumer services. Exceptions are certain types of activities of business entities, provided that personnel and visitors are provided with personal protective equipment (including respirators or protective masks, including self-made ones), and compliance with appropriate sanitary and anti-epidemic measures. The following activities of economic entities include:

- trade in food, hygiene products, medicines and medical devices, veterinary preparations, fuel, parts and accessories for vehicles and agricultural machinery, technical and other means of rehabilitation, feeds, pesticides and agrochemicals, seeds and planting material, means of communication and telecommunications (no more than one visitor per 10 square meters of retail space is allowed in the premises);

- medical practice, activities for the manufacture of technical and other means of rehabilitation, veterinary practice;

- conducting activities for providing financial services, activities of financial institutions and activities for collection and transportation of currency values;

- activity of gas stations, sales, leasing, technical maintenance and repair of vehicles, periodic tests of vehicles for road safety, certification of vehicles, their parts and equipment, maintenance of registrars of settlement operations;

- trading and catering activities using targeted delivery of orders;

- activities on connection of consumers to the Internet, replenishment of accounts of mobile communication, payment of utilities and services of access to the Internet, repair of office and computer equipment, equipment, supplies, household goods and personal consumption items, postal service providers, qualified electronic trust service providers;

- activities of accommodation establishments in which health care workers and persons under observation reside, as well as other persons in accordance with the decision of the State Commission on Technogenic and Environmental Safety and Emergency Situations (Resolution of the Cabinet of Ministers of Ukraine № 225, 2020).

According to the Resolution of the Cabinet of Ministers of Ukraine № 255 of April 2, 2020, it is also prohibited to hold all mass (cultural, entertaining, sports, social, religious, advertising and other) events, except for the measures necessary to ensure the work of state and local self-government bodies, provided that participants are provided with personal protective equipment, including respirators or protective masks, including self-made ones, as well as compliance with appropriate sanitary and anti- 
epidemic measures, etc. It is allowed for individual entrepreneurs and individuals who carry out independent professional activity, temporarily, for the period of quarantine, to keep records of income and expenses without using books of income and expense accounting (books of income) if these books are to be started after quarantining. The Resolution states that this is possible subject to further submission by such persons of books of income and expenses (books of income), which contain data on income and expenses received (made) by them during quarantine, for registration to the controlling bodies within three months from on the day of the decision to cancel the quarantine (Resolution of the Cabinet of Ministers of Ukraine № 225, 2020).

In order to prevent the spread in Ukraine of acute respiratory disease COVID-19 caused by the coronavirus SARS-CoV-2 as early as March 17, 2020 a number of important regulatory acts were adopted regulating the activity of economic entities (establishing privileges for taxpayers, restrictions on transportation anti-epidemic goods outside the customs territory of Ukraine, regulation of holidays, etc.):

1) by The Law of Ukraine dated 17.03.2020 № 530-IX during the quarantine prohibited the carrying out of scheduled checks in the sphere of economic activity, allowed the performance of work remotely (at home), introduced administrative penalties and increased criminal liability for quarantine violations. According to the Law, quarantine is considered force majeure (Law of Ukraine № 530-IX, 2020);

2) by The Law of Ukraine of March 17, 2020 № 531-IX defines a person authorized to make health care purchases, which is a legal entity (procurement organization), established by a central body of executive power, which ensures the formation and implementation of state policy in the field of health care, and is authorized to procure medicines, medical devices, other goods and services at the expense of the state budget, as well as at the expense of grants (sub-grantees) for the implementation of the Global Fund programs. According to the Law registration certificates for medicinal products purchased by specialized procurement organizations have been extended until March 31, 2022 (Law of Ukraine № 531-IX, 2020);

3) bylaw dated March 17,2020, №532-IX, temporarily, untilDecember31,2022, the following operations shall be exempted from VAT: a) operations on theimportation into the customs territory of Ukraine of medicines, medical devices and auxiliaries funds for them, which are procured at the expense of the state budget by a person authorized to make purchases in the healthcare sector (for the implementation of programs and implementation of centralized health care measures); b) operations for the supply in the customs territory of Ukraine of medicines, medical devices and auxiliaries to them, purchased at the expense of the state budget by a person authorized to make purchases in the field of health care (for the implementation of programs and implementation of centralized health care measures'). The provisions of Clause 198.5 and Article 199 of the Tax Code of Ukraine do not apply; c) operations for free supply (transfer) by a person authorized to carry out purchases in the field of health care, medicines, medical devices and auxiliary products to them, which have been imported and / or 
delivered in the customs territory of Ukraine for the benefit of structural units on issues health care of regional, Kyiv and Sevastopol city state administrations or economic entities licensed to conduct business activities in medical practice, etc. (Law of Ukraine № 532-IX, 2020);

4) according to the Law of Ukraine dated March 17, 2020, № 533-IX, it is provided that no penalties will be applied for violations of tax legislation committed from March 1 to May 31, 2020; establishes a moratorium on documentary and factual inspections of the MRF from March 18 to May 31 2020; the annual income statement is extended until July 1, 2020; provisionally exempt from the calculation and payment of the ESAs all natural persons-entrepreneurs, persons engaged in independent professional activity and members of the farm for the period from March 1 to March 31 and from April 1 to April 30, 2020 for themselves; the payment for the land is not accrued or paid in the period from March 1 to April 30, 2020; non-residential real estate owned by natural or legal persons will not be considered as subject to real estate tax for the period from March 1 to April 30, 2020, etc. (Law of Ukraine № 533-IX, 2020).

The Resolution of the Cabinet of Ministers of Ukraine № 224 of March 20, 2020 approved the list of medicines, medical devices and / or medical equipment necessary for the implementation of measures aimed at preventing the occurrence and spread pandemics of coronavirus disease (COVID-19) which are exempted from import duties and operations for the importation of which into the customs territory of Ukraine are exempt from VAT: 1) medicines for the provision of medical care to patients with COVID-19;2) disinfectants and antiseptics; 3) medical equipment for health care facilities to assist patients with COVID-19, including artificial lung ventilation, non-invasive ventilation system (BIPAP / CPAP), personal protective equipment, medical devices for screening patients, etc. (Resolution of the Cabinet of Ministers of Ukraine № 224, 2020).

\section{The essence of state policy against entrepreneurial activity during quarantine in Ukraine}

Small and medium-sized businesses are unquestionably considered the most vulnerable to shocks and disasters a segment of the economy not only in Ukraine but worldwide. Therefore, in the context of quarantine and the financial crisis, measures aimed at ensuring the survival of small businesses became one of the first anti-crisis steps in many countries of the world. After all, the well-being of almost tens of millions of families, not only the businessmen and self-employed persons, but also their employees, depends on it.

In the USA small businesses will receive $\$ 1.8$ billion under a new payroll protection program, which provides interest-free loans to cover wage costs. If staffing positions are retained throughout the quarantine period, the borrowed money may not be refunded. Switzerland plans to spend 40 billion francs (almost $\$ 41$ billion) on its interest-free business lending program. Similar mechanisms are introduced by other developed countries (Obukh, 
2020). In Ukraine, there is no way to use this scale of financial resources, so the government goes through the introduction of tax preferences and easing fiscal pressure.

The Government is constantly undertaking measures to support business entities, in particular entrepreneurship. Thus, the Cabinet of Ministers of Ukraine has made a decision to provide additional social guarantees for the quarantine period for individuals-entrepreneurs who have children and people who have lost their jobs and registered at the employment center as unemployed. In particular, the Government's decision introduced the payment of child support to individual entrepreneurs who belong to the first and second group of single tax payers and paid a single social contribution, for the period of quarantine and for one month after the date of its abolition. Such assistance will be provided for each child up to 10 years of age in the amount of the subsistence minimum (for children under 6 years - UAH 1,779; for children between 6 and 10 years - UAH 2 218). The term of overdue arrears on payment of housing and communal services to recipients of housing subsidies and privileges, for which a housing subsidy is not assigned, was also extended from two to three months (The only web portal of the executive authorities of Ukraine "Government Portal"d).

In the context of the COVID-19 pandemic and quarantine throughout the country, it is envisaged to channel funds allocated by the European Union to support Ukraine (EUR 190 million) not only to support the healthcare system (about EUR 15 million) and the economy (EUR 61 million), but also to support small and medium-sized enterprises (EUR 20 million), small farms (EUR 25 million) (Kuleba, 2020).

The state takes all necessary measures during quarantine conditions in order to support business entities and reduce the negative effects of the coronavirus pandemic in the country's economy. However, there are also some problematic areas that need to be addressed. Thus, from March 1 to April 30, 2020, individual entrepreneurs are exempted from paying ESAs. If individual entrepreneurs have paid this contribution in advance for March and April, then these funds will automatically be credited as payment for subsequent periods. However, the contribution for March and April of individual entrepreneurs working on all tax systems, self-employed persons and members of farms does not pay only for themselves. This is not the case for their employees. That is, a small business owner with several employees must pay more than UAH 1000 for each employee on a monthly basis, although in a quarantine environment, the company does not work and does not make a profit. There are many such problematic areas and all of them need to be addressed and regulated at the legislative level.

According to the author, it would be expedient to support small and medium entrepreneurs not only by the implemented measures (in particular, the abolition of scheduled inspections during quarantine, or the abolition of fines for late payments), but, above all, permission for other categories of entrepreneurs to conditions for compliance with the rules for providing staff and visitors with personal 
protective equipment (respirators or protective masks, including self-made), as well as compliance with the relevant and anti-epidemic measures (in particular, staying in the premises of not more than one visitor per 10 square meters). This proposal is especially relevant given the extension of quarantine for an indefinite period and in the context of reducing the attack of coronavirus around the world.

\section{Conclusions}

The introduction of quarantine throughout Ukraine to prevent and counteract the spread of the coronavirus pandemic has directly affected the activities of business entities. Most small and medium-sized businesses are on the brink of survival.

The government of Ukraine goes through the introduction of tax preferences and easing fiscal pressure. The authorities have taken a number of measures to regulate holidays, restrict the transportation of certain anti-epidemic goods outside the customs territory of Ukraine, etc., as well as introduce administrative penalties and increase criminal liability for violations of quarantine rules, sanitary and anti-epidemic rules and regulations. However, there are a number of problematic areas and they all need to be addressed and regulated at the legislative level. In terms of prolonging quarantine and in the context of reducing coronavirus attacks worldwide, it would be appropriate to allow small and medium-sized enterprises to operate subject to all necessary sanitary and anti-epidemic measures.

It is advisable to amend the legislation in force in order to harmonize it with:

a) adoption at the legislative level of a number of legal acts aimed at preventing the spread of acute COVID-19 respiratory disease caused by the SARS-CoV-2 coronavirus in Ukraine, which significantly affected the activities of economic entities during quarantine;

b) replace in the legislative and other normative acts the statement: "acute respiratory illness COVID-19 caused by the coronavirus SARS-CoV-2" instead of "coronavirus COVID-19", which was used in the legislation before the Cabinet of Ministers of Ukraine adopted Resolution April 02, 2020, № 255.

\section{Bibliography:}

1. Попова Л.М. Адміністративно-правові засади контролю в сфері підприємницької діяльності : дисертація д-ра юрид. наук : спец. 12.00.07. Харків, 2018. 524 с.

2. Попова Л.М. Адміністративно-правові засади контролю в сфері підприємницької діяльності : автореф. дис. ... д-ра юрид. наук : спец. 12.00.07. Харків, 2019. 38 с.

3. Про захист населення від інфекційних хвороб : Закон України від 06.04.2000 р. № 1645-III. URL: https://zakon.rada.gov.ua/laws/show/1645-14 (дата звернення: 22.04.2020).

4. ПрозапобіганняпоширеннюнатериторіїУкраїникоронавірусу COVID-19:Постанова Кабінету Міністрів України від 11 березня 2020 р. № 211. URL: https://www.kmu.gov.ua/ npas/pro-zapobigannya-poshim110320rennyu-na-teritoriyi-ukrayini-koronavirusu-covid-19 (дата звернення: 22.04.2020).

5. Загальнонаціональний карантин продовжено до 24 квітня - рішення уряду. Єдиний вебпортал органів виконавчої влади України «Урядовий портал». URL: https://www.kmu.gov.ua/news/zagalnonacionalnij-karantin-prodovzheno-do-24-kvitnyarishennya-uryadu (дата звернення: 22.04.2020). 
6. Уряд продовжив карантин до 11 травня. Єдиний веб-портал органів виконавчої влади «Урядовий портал», 22 квітня 2020 p. URL: https://www.kmu.gov.ua/news/uryadprodovzhiv-karantin-do-11-travnya (дата звернення: 22.04.2020).

7. Уряд запровадив режим надзвичайної ситуації на всій території України. Офіційний вебпортал органів виконавчої влади «Урядовий портал», 25.03.2020 р. URL: https://www.kmu.gov.ua/news/uryad-zaprovadiv-rezhim-nadzvichajnoyi-situaciyi-po-vsijteritoriyi-ukrayini (дата звернення: 22.04.2020).

8. Про внесення змін до деяких законодавчих актів України, спрямованих на запобігання виникненню і поширенню коронавірусної хвороби (COVID-19): Закон України від 17.03.2020 p. № 530-IX. URL: https://zakon.rada.gov.ua/laws/show/530-20 (дата звернення: 22.04.2020).

9. Про внесення змін до Податкового кодексу України та інших законів України щодо підтримки платників податків на період здійснення заходів, спрямованих на запобігання виникненню і поширенню коронавірусної хвороби (COVID-19) : Закон України від 17.03.2020 p. № 533-IX. URL: https://zakon.rada.gov.ua/laws/show/533-20 (дата звернення: 22.04.2020).

10. Про затвердження переліку лікарських засобів, медичних виробів та/або медичного обладнання, необхідних для здійснення заходів, спрямованих на запобігання виникненню і поширенню, локалізацію та ліквідацію спалахів, епідемій та пандемій коронавірусної хвороби (COVID-19), які звільняються від сплати ввізного мита, та операції 3 ввезення яких на митну територію України звільняються від оподаткування податком на додану вартість: Постанова Кабінету Міністрів України від 21.03.2020 p. № 224. URL: https://www.kmu.gov.ua/npas/pro-zatverdzhennya-pereliku-likarskih-zasobiv-medichnihvirobiv-taabo-224200320 (дата звернення: 22.04.2020).

11. Про внесення змін до постанови Кабінету Міністрів України від 11 березня 2020 p. № 211 : Постанова Кабінету Міністрів України від 02 квітня 2020 р. № 255. URL:https://www.kmu.gov.ua/npas/pro-vnesennya-zmin-do-postanovi-kabinetu-ministriv-ukrm020420ayini-vid-11-bereznya-2020-r-211 (дата звернення: 22.04.2020).

12. Про внесення змін до деяких законів України, спрямованих на підвищення доступності лікарських засобів, медичних виробів та допоміжних засобів до них, які закуповуються особою, уповноваженою на здійснення закупівель у сфері охорони здоров’я: Закон України від 17.03.2020 р. № 531-IX. URL: https://zakon.rada.gov.ua/laws/ show/531-20 (дата звернення: 22.04.2020).

13. Про внесення змін до Податкового кодексу України щодо підвищення доступності лікарських засобів, медичних виробів та допоміжних засобів до них, які закуповуються за кошти державного бюджету, та створення умов для закупівель у сфері охорони здоров’я за кошти державного бюджету : Закон України від 17.03.2020 p. № 532-IX. URL: https://zakon.rada.gov.ua/laws/show/532-20 (дата звернення: 22.04.2020).

14. Обух В. Як вижити ФОПам під час карантину. Мультимедійнаплатформа іномовлення України «Укрінформ». URL: https://www.ukrinform.ua/rubric-economy/3000269-karantinnapidtrimka-fopiv-efektivna-ci-ak-mertvomu-priparka.html (дата звернення: 22.04.2020).

15. Уряд запровадив додаткові соціальні гарантії для ФОПів та малозабезпечених сімей на період карантину. Єдиний веб-портал органів виконавчої влади «Урядовий портал», 22 квітня 2020 p. URL: https://www.kmu.gov.ua/news/uryad-zaprovadiv-dodatkovisocialni-garantiyi-dlya-fopiv-ta-malozabezpechenih-simej-na-period-karantinu (дата звернення: 22.04.2020).

16. Дмитро Кулеба: 190 мільйонів євро від ЄС підтримають систему охорони здоров'я, малий та середній бізнес і найбільш вразливі групи населення. Єдиний веб-портал органів 
виконавчої влади «Урядовий портал», 21 квітня 2020 p. URL: https:/www.kmu.gov.ua/news/ dmitro-kuleba-190-miljoniv-yevro-vid-yes-pidtrimayut-sistemu-ohoroni-zdorovya-malij-taserednij-biznes-i-najbilsh-vrazlivi-grupi-naselennya (дата звернення: 22.04.2020).

\section{References:}

1. Popova, L.M. (2018) Administratyvno-pravovi zasady kontroliu v sferi pidpryiemnytskoi diialnosti [Administrative and legal bases of control in the field of entrepreneurial activity]: dysertatsiia d-ra yuryd. nauk : spets. 12.00.07. Kharkiv. 524 s. [in Ukrainian].

2. Popova, L.M. (2019) Administratyvno-pravovi zasady kontroliu v sferi pidpryiemnytskoi diialnosti [Administrative and legal bases of control in the field of entrepreneurial activity]: Avtoref. dys. ... d-ra yuryd. nauk : spets. 12.00.07. Kharkiv. 38 s. [in Ukrainian].

3. Verkhovna Rada of Ukraine (2000). Pro zakhyst naselennia vid infektsiinykh khvorob : Zakon Ukrainy vid 06.04.2000 r. № 1645-III (stanom na 22 kvitnia 2020 r.) [On protection against infectious diseases: Law of Ukraine of April 06, 2000 № 1645-III (as of April 22, 2020)]. Retrieved from: https://zakon.rada.gov.ua/laws/show/1645-14 [in Ukrainian].

4. Kabinet Ministriv Ukrainy (2020). Pro zapobihannia poshyrenniu na terytorii Ukrainy koronavirusu COVID-19 : Postanova Kabinetu Ministriv Ukrainy vid 11 bereznia 2020 r. № 211 (stanom na 22 kvitnia 2020 r.) [On the Prevention of COVID-19 Coronavirus Spread in Ukraine: Resolution of the Cabinet of Ministers of Ukraine of March 11,2020 No 211 (as of April 22, 2020)]. Retrieved from: https://www.kmu.gov.ua/npas/pro-zapobigannya-poshim110320rennyuna-teritoriyi-ukrayini-koronavirusu-covid-19 [in Ukrainian].

5. The only web portal of the executive bodies of Ukraine (2020). Zahalnonatsionalnyi karantyn prodovzheno do 24 kvitnia - rishennia uriadu. Yedynyi veb-portal orhaniv vykonavchoi vlady Ukrainy «Uriadovyi portal» (stanom na 22 kvitnia 2020 r.) [National quarantine extended until April 24 - government decision. The only web portal of the executive bodies of Ukraine is the Government Portal (as of April 22, 2020)]. Retrieved from: https://www.kmu.gov.ua/news/ zagalnonacionalnij-karantin-prodovzheno-do-24-kvitnya-rishennya-uryadu [in Ukrainian].

6. The only web portal of the executive bodies of Ukraine (2020). Uriad prodovzhyv karantyn do 11 travnia. Yedynyi veb-portal orhaniv vykonavchoi vlady "Uriadovyi portal", 22 kvitnia 2020 r. (stanom na 22 kvitnia 2020 r.) [The government extended the quarantine until May 11. The only web portal of the executive bodies of the Government Portal, April 22, 2020 (as of April 22, 2020)] Retrieved from: https://www.kmu.gov.ua/news/uryad-prodovzhiv-karantin-do-11-travnya [in Ukrainian].

7. The only web portal of the executive bodies of Ukraine (2020). Uriad zaprovadyv rezhym nadzvychainoi sytuatsii na vsii terytorii Ukrainy. Ofitsiinyi vebportal orhaniv vykonavchoi vlady "Uriadovyi portal", 25.03.2020 r. (stanom na 22 kvitnia 2020 r.) [The government has introduced an emergency regime throughout Ukraine. Official web-portal of executive authorities "Government portal", March 25, 2020 (as of April 22, 2020)] Retrieved from: https://www.kmu.gov.ua/news/uryad-zaprovadiv-rezhim-nadzvichajnoyi-situaciyi-po-vsijteritoriyi-ukrayini [in Ukrainian].

8. Verkhovna Rada of Ukraine (2020). Pro vnesennia zmin do deiakykh zakonodavchykh aktiv Ukrainy, spriamovanykh na zapobihannia vynyknenniu i poshyrenniu koronavirusnoi khvoroby (COVID-19): Zakon Ukrainy vid 17.03.2020 r. № 530-IX (stanom na 22 kvitnia 2020 r.) [On Amendments to certain legislative acts of Ukraine aimed at preventing the emergence and spread of coronavirus disease (COVID-19): Law of Ukraine of 17.03.2020 No. 530-IX (as of April 22, 2020)]. Retrieved from: https://zakon.rada.gov.ua/laws/show/530-20 [in Ukrainian].

9. Verkhovna Rada of Ukraine (2020). Pro vnesennia zmin do Podatkovoho kodeksu Ukrainy ta inshykh zakoniv Ukrainy shchodo pidtrymky platnykiv podatkiv na period zdiisnennia 
zakhodiv, spriamovanykh na zapobihannia vynyknenniu i poshyrenniu koronavirusnoi khvoroby (COVID-19): Zakon Ukrainy vid 17.03.2020 r. № 533-IX (stanom na 22 kvitnia 2020 r.) [On Amendments to the Tax Code of Ukraine and Other Laws of Ukraine on Support of Taxpayers for the Period of Measures to Prevent the Occurrence and Spread of Coronavirus Disease (COVID-19): Law of Ukraine of March 17, 2020, No. 533-IX (as of April 22, 2020)]. Retrieved from: https://zakon.rada.gov.ua/laws/show/533-20 [in Ukrainian].

10. Kabinet Ministriv Ukrainy (2020). Pro zatverdzhennia pereliku likarskykh zasobiv, medychnykh vyrobiv ta/abo medychnoho obladnannia, neobkhidnykh dlia zdiisnennia zakhodiv, spriamovanykh na zapobihannia vynyknenniu i poshyrenniu, lokalizatsiiu ta likvidatsiiu spalakhiv, epidemii ta pandemii koronavirusnoi khvoroby (COVID-19), yaki zvilniaiutsia vid splaty vviznoho myta ta operatsii z vvezennia yakykh na mytnu terytoriiu Ukrainy zvilniaiutsia vid opodatkuvannia podatkom na dodanu vartist: Postanova Kabinetu Ministriv Ukrainy vid 21.03.2020 r. № 224 (stanom na 22 kvitnia 2020 r.) [On Approving the List of Medicines, Medical Devices and / or Medical Equipment Required for the Implementation of Measures to Prevent the Occurrence and Dissemination, Localization and Elimination of Outbreaks, Epidemics and Pandemics of Coronavirus Disease (COVID-19) exempted from import duties and transactions for the importation into the customs territory of Ukraine of which are exempt from value added tax : Resolution of the Cabinet of Ministers of Ukraine of March 21, 2020 No 224 (as of April 22, 2020)]. Retrieved from: https://www.kmu.gov.ua/npas/pro-zatverdzhennya-pereliku-likarskihzasobiv-medichnih-virobiv-taabo-224200320 [in Ukrainian].

11. Kabinet Ministriv Ukrainy (2020). Pro vnesennia zmin do postanovy Kabinetu Ministriv Ukrainy vid 11 bereznia 2020 r. № 211: Postanova Kabinetu Ministriv Ukrainy vid 02 kvitnia 2020 r. № 255 (stanom na 22 kvitnia 2020 r.) [On Amendments to the Resolution of the Cabinet of Ministers of Ukraine of March 11, 2020 No 211: Resolution of the Cabinet of Ministers of Ukraine of April 2, 2020 No 255 (as of April 22, 2020)]. Retrieved from: https://www.kmu.gov.ua/ npas/pro-vnesennya-zmin-do-postanovi-kabinetu-ministriv-ukrm020420ayini-vid-11-bereznya2020-r-211 [in Ukrainian].

12. Verkhovna Rada of Ukraine (2020). Pro vnesennia zmin do deiakykh zakoniv Ukrainy, spriamovanykh na pidvyshchennia dostupnosti likarskykh zasobiv, medychnykh vyrobiv ta dopomizhnykh zasobiv do nykh, yaki zakupovuiutsia osoboiu, upovnovazhenoiu na zdiisnennia zakupivel u sferi okhorony zdorov'ia : Zakon Ukrainy vid 17.03.2020 r. № 531-IX (stanom na 22 kvitnia 2020 r.) [On Amendments to certain laws of Ukraine aimed at increasing the availability of medicines, medical devices and auxiliaries to them procured by a person authorized to make health care purchases: Law of Ukraine of March 17, 2020 No. 531-IX (as of April 22, 2020)]. Retrieved from: https://zakon.rada.gov.ua/laws/ show/531-20 [in Ukrainian].

13. Verkhovna Rada of Ukraine (2020). Pro vnesennia zmin do Podatkovoho kodeksu Ukrainy shchodo pidvyshchennia dostupnosti likarskykh zasobiv, medychnykh vyrobiv ta dopomizhnykh zasobiv do nykh, yaki zakupovuiutsia za koshty derzhavnoho biudzhetu, ta stvorennia umov dlia zakupivel u sferi okhorony zdorov'ia za koshty derzhavnoho biudzhetu : Zakon Ukrainy vid 17.03.2020 r. № 532-IX (stanom na 22 kvitnia 2020 r.) [On Amendments to the Tax Code of Ukraine on Increasing the Availability of Medicines, Medical Devices and Auxiliaries to them Purchased from the State Budget and Creating Conditions for Health Procurement at the State Budget: Law of Ukraine of 03/17/2020 No. 532-IX (as of April 22, 2020)]. Retrieved from: https://zakon.rada.gov.ua/laws/show/532-20 [in Ukrainian].

14. Obukh, V (2020). Yak vyzhyty FOPam pid chas karantynu. Multymediina platforma inomovlennia Ukrainy „Ukrinform” (stanom na 22 kvitnia 2020 r.) [How to Survive Individual Entrepreneurs during Quarantine. Multimedia Broadcasting Platform of Ukraine "Ukrinform" 


\title{
ОСОБЛИВЕ АДМІНІСТРАТИВНЕ ПРАВО
}

(as of April 22, 2020)]. Retrieved from: https://www.ukrinform.ua/rubric-economy/3000269karantinna-pidtrimka-fopiv-efektivna-ci-ak-mertvomu-priparka.html [in Ukrainian].

15. The only web portal of the executive bodies of Ukraine (2020). Uriad zaprovadyv dodatkovi sotsialni harantii dlia FOPiv ta malozabezpechenykh simei na period karantynu. Yedynyi veb-portal orhaniv vykonavchoi vlady "Uriadovyi portal", 22 kvitnia 2020 r. (stanom na 22 kvitnia 2020 r.) [The Government has introduced additional social guarantees for individuals entrepreneurs and low-income families for the quarantine period. The only web portal of the executive bodies of the Government Portal, April 22, 2020 (as of April 22, 2020)]. Retrieved from: https://www.kmu.gov.ua/news/uryad-zaprovadiv-dodatkovi-socialni-garantiyi-dlya-fopiv-tamalozabezpechenih-simej-na-period-karantinu [in Ukrainian].

16. Kuleba, D. (2020). 190 milioniv yevro vid YeS pidtrymaiut systemu okhorony zdorov'ia, malyi ta serednii biznes i naibilsh vrazlyvi hrupy naselennia. Yedynyi veb-portal orhaniv vykonavchoi vlady "Uriadovyi portal", 21 kvitnia 2020 r. (stanom na 22 kvitnia 2020 r.) [EUR 190 million from the European Union will support the healthcare system, small and mediumsized businesses and the most vulnerable. The only Web Portal for Government Authorities, April 21, 2020 (as of April 22, 2020)]. Retrieved from: https://www.kmu.gov.ua/news/dmitro-kuleba190-miljoniv-yevro-vid-yes-pidtrimayut-sistemu-ohoroni-zdorovya-malij-ta-serednij-biznes-inajbilsh-vrazlivi-grupi-naselennya [in Ukrainian].

\section{ОСОБЛИВОСТІ АДМІНІСТРАТИВНО-ПРАВОВОГО РЕГУЛЮВАННЯ ДІЯЛЬНОСТІ СУБ'ЄКТІВ ГОСПОДАРЮВАННЯ ПІД ЧАС КАРАНТИНУ}

\author{
Лілія Попова, \\ професор кафедри фінансів та кредиту \\ Харківського національного університету будівництва та архітектури, \\ доктор юридичних наук, кандидат економічних наук, доцент \\ orcid.org/0000-0001-8255-8363 \\ Liliya.herman01@gmail.com
}

Мета статті - дослідити особливості адміністративно-правового регулювання діяльності суб'єктів господарювання під час карантину та розглянути можливі напрями вдосконалення такого регулювання.

Методи. Теоретико-методологічною основою дослідження є сучасні загальнонаукові та спеціально-правові методи та прийоми наукового пізнання. Формально-логічний метод визначае важливість адміністративно-правового регулювання діяльності суб'єктів господарювання під час карантину. Формально-правовий метод дозволив проаналізувати діючі законодавчі та інші нормативно-правові акти, щзо стосуються адміністративно-правового регулювання діяльності суб'єктів господарювання під час карантину. Структурно-логічні, порівняльно-правові методи окреслюють основні напрями вдосконалення здійснення адміністративно-правового регулювання діяльності суб'єктів господарювання під час карантину.

Результати. Звертається увага на те, щуо суб 'єкти господарювання обмежені у своїх діях через введення карантину та надзвичайного режиму в Украйні. У статті проаналізовано законодавчі та інші правові акти, прийняті для запобігання розповсюдженню в Україні гострого респіраторного захворювання COVID-19, спричиненого коронавірусом SARS-CoV-2, які регулюють діяльність суб 'єктів господарювання. Зазначається, що уряд держави, беручи до уваги важливу роль суб'єктів господарювання в економічі країни, 
вживає розсудливих заходів для їх підтримки під час карантину. Однак існують певні умови, за яких суб'єкти господарювання стикаються з проблемами, які потребують вирішення насамперед на законодавчому рівні.

Висновки. У статті вказано на доиільність внесення змін до чинного законодавства для його гармонізаиії у зв 'язку з прийняттям ряду нормативно-правових актів, спрямованих на запобігання розповсюдженню в Україні гострого респіраторного захворювання COVID-19, спричиненого коронавірусом SARS-CoV-2, та використанням в законодавстві різної термінологї, що стосується COVID-19.

Ключові слова: адміністративно-правові норми, пандемія коронавірусу, надзвичайна ситуація, протидія пандемії коронавірусу, пільги, відповідальність суб' єктів господарювання. 